\title{
(D-Ala²)Deltorphin II: $\mathrm{D}_{1}$-dependent Stereotypies and Stimulation of Dopamine Release in the Nucleus Accumbens
}

\author{
R. Longoni, ${ }^{1}$ L. Spina, ${ }^{1}$ A. Mulas, ${ }^{1}$ E. Carboni, ${ }^{1}$ L. Garau, ${ }^{1}$ P. Melchiorri, ${ }^{2}$ and G. Di Chiara ${ }^{1}$ \\ Institute of Experimental Pharmacology and Toxicology, University of Cagliari, 09100 Cagliari, Italy and Institute of \\ Medical Pharmacology, University of Rome "La Sapienza," 00185 Rome, Italy
}

In order to investigate the relative role of central $\delta$ - and $\mu$-opioid receptors in behavior, the effects of (DAla ${ }^{2}$ )deltorphin II, a natural $\delta$-opioid peptide, and PL017, a beta-casomorphin derivative specific for mu receptors, were compared after local intracerebral and intraventricular administration. Intracerebral infusion of the two peptides was done bilaterally in the limbic nucleus accumbens and in the ventral and dorsal caudate putamen of freely moving rats through chronic intracerebral cannulas. After intra-accumbens infusion, the two peptides elicited marked but opposite behavioral effects: while (D-Ala ${ }^{2}$ )deltorphin II evoked dosedependent motor stimulation characterized by locomotion, sniffing, and oral stereotypies, PL017 elicited motor inhibition with rigidity and catalepsy. These effects were site specific because they could not be evoked from the ventral or from the dorsal caudate. Low doses of naloxone $10.1 \mathrm{mg} /$ $\mathrm{kg}$, s.c.) blocked the effects of PL017 but not those of (D$\mathrm{Ala}^{2}$ )deltorphin II, which instead were reduced by high doses of naloxone $(1.0 \mathrm{mg} / \mathrm{kg})$ and by the putative $\delta$-antagonist naltrindole; this drug failed to affect the catalepsy induced by PL017. Therefore, while (D-Ala ${ }^{2}$ )deltorphin II effects were $\delta$-mediated, PL017 effects were $\mu$-mediated. Blockade of dopamine $D_{1}$ receptors by SCH 23390 abolished (DAla ${ }^{2}$ )deltorphin II effects, while blockade of dopamine $D_{2}$ receptors by raclopride or by haloperidol was without effect. Local application by reverse dialysis of (D-Ala $\left.{ }^{2}\right)$ deltorphin II $(5 \mu \mathrm{M})$ to the accumbens resulted in a naloxone-sensitive increase of extracellular dopamine concentrations; these effects could not be evoked from the caudate, nor by PL017 in the accumbens. Intracerebroventricular administration of (D-Ala ${ }^{2}$ )deltorphin II or of PL017 elicited behavioral effects qualitatively similar to those obtained from the accumbens.

Opioids are known to influence behavior in a complex, often biphasic manner (Babbini and Davis, 1972; Domino et al., 1976; Costall et al., 1978; Tortella et al., 1978). On the basis of local intracerebral administration and electrophysiological studies (Broekkamp et al., 1979; Kelley et al., 1980; Stinus et al., 1980; Matthews and German, 1984; Latimer et al., 1987); and, more recently, of brain dialysis studies in freely moving rats (Di Chiara and Imperato, 1988a,b; Di Chiara, 1990), limbic dopamine (DA)

Received June 19, 1990; revised Nov. 5, 1990; accepted Dec. 28, 1990.

This work was supported by funds from M.U.R.S.T. and C.N.R. (Sp4, Medicina Preventiva and Comitato Tecnologico).

Correspondence should be addressed to Professor Gaetano Di Chiara, Institute of Experimental Pharmacology and Toxicology, University of Cagliari, Viale A. Diaz 182, 09100 Cagliari, Italy.

Copyright (C) 1991 Society for Neuroscience $0270-6474 / 91 / 111565-12 \$ 03.00 / 0$ has been implicated in the stimulant actions of systemic opiates. Morphine-like opiates stimulate DA release preferentially in the nucleus accumbens (Di Chiara and Imperato, 1988a) and elicit hypermotility sensitive to blockade by the $\mathrm{DA}_{1}$ receptor antagonist SCH 23390 (Longoni et al., 1987a). Intra-accumbens infusion of opioid peptides elicits motor stimulation, but this action seems independent from DA, being resistant to classic DA-receptor antagonists (neuroleptics; Pert and Sivit, 1977; Kalivas et al., 1983). Moreover, the syndrome elicited by intraaccumbens opiates is biphasic, as motor stimulation is typically preceded by motor inhibition and catalepsy (Costall et al., 1978). This biphasic character might be due to differential behavioral properties of $\mu$-versus $\delta$-receptor stimulation in the accumbens (Havemann and Kuschinsky, 1985; Daugé et al., 1988). However, no clearcut demonstration exists for separate $\mu / \delta$ functions in the CNS, and some authors have even suggested that $\delta$-receptors cooperate with $\mu$-receptors for functional expression (Vaught and Takemori, 1979; Rothman and Westfall, 1982). Clarification of this issue rests on the availability of potent and specific agonists of, respectively, $\mu$ - and $\delta$-opioid receptors. While specific $\mu$-agonist peptides have only been known for a few years (Chang et al., 1983), information about specific and high-intrinsic-activity $\delta$-agonists had been lacking until the recent availability of (D-Ala ${ }^{2}$ )deltorphin II (Tyr-D-Ala-Phe-Glu-Val-Val-Gly$\mathrm{NH}_{2}$ ), a peptide extracted from the skin of a South American frog (Erspamer et al., 1989); with this $\delta$-agonist and with PL017 as a specific $\mu$-agonist (Blanchard et al., 1987), we have undertaken a study of the behavioral and biochemical effects of the selective stimulation of $\mu$ - and $\delta$-opioid receptors in the rat nucleus accumbens.

\section{Materials and Methods}

Animals. Male Spraque-Dawley rats (Charles River; 280-300 gm) were used. Animals were housed in groups of six under constant temperature $\left(21^{\circ} \mathrm{C}\right)$ and humidity and a light-dark cycle of $12 \mathrm{hr}$ (light at 7:00). Food and water were available ad libitum. All experiments were performed between 8:00 and 13:00.

Surgery and injection procedure. Rats were anesthetized with Equithesin (pentobarbital, $0.8 \mathrm{gm}$; chloral hydrate, $4.25 \mathrm{gm}$; $\mathrm{MgSO}_{4}, 2.12$ $\mathrm{gm}$; propylene glycol, $40 \mathrm{ml}$; alcohol $95 \%, 10 \mathrm{ml} ; \mathrm{H}_{2} \mathrm{O}, 34 \mathrm{ml}$ ), placed on a David Kopf stereotaxic apparatus, and implanted bilaterally with permanent cannulas fixed to the skull using acrylic cement. Guide cannulas (22-gauge stainless steel) were positioned $2 \mathrm{~mm}$ above the intended injection site. Coordinates were accumbens: A, 3.4; L, 2; V, 7.2; dorsal caudate: $A, 1.6 ; \mathrm{L}, 3.2 ; \mathrm{V}, 5$ or 4 ; ventral caudate: $\mathrm{A}, 2.8 ; \mathrm{L}, 3.5 ; \mathrm{V}$, 7.2; lateral ventricle: A, 0; L, 1.5; V, 3.2 (Pellegrino et al., 1979). Stilets were inserted in the guide cannulas, and the animals were housed individually for recovery.

The drugs were injected by an infusion pump in a volume of 0.5 or $1 \mu \mathrm{l}$ of saline at a rate of $0.5 \mu \mathrm{l} / \mathrm{min}$. Intracerebroventricular injections were made bilaterally in a volume of $5 \mu \mathrm{l}$ for each side. After infusion, 


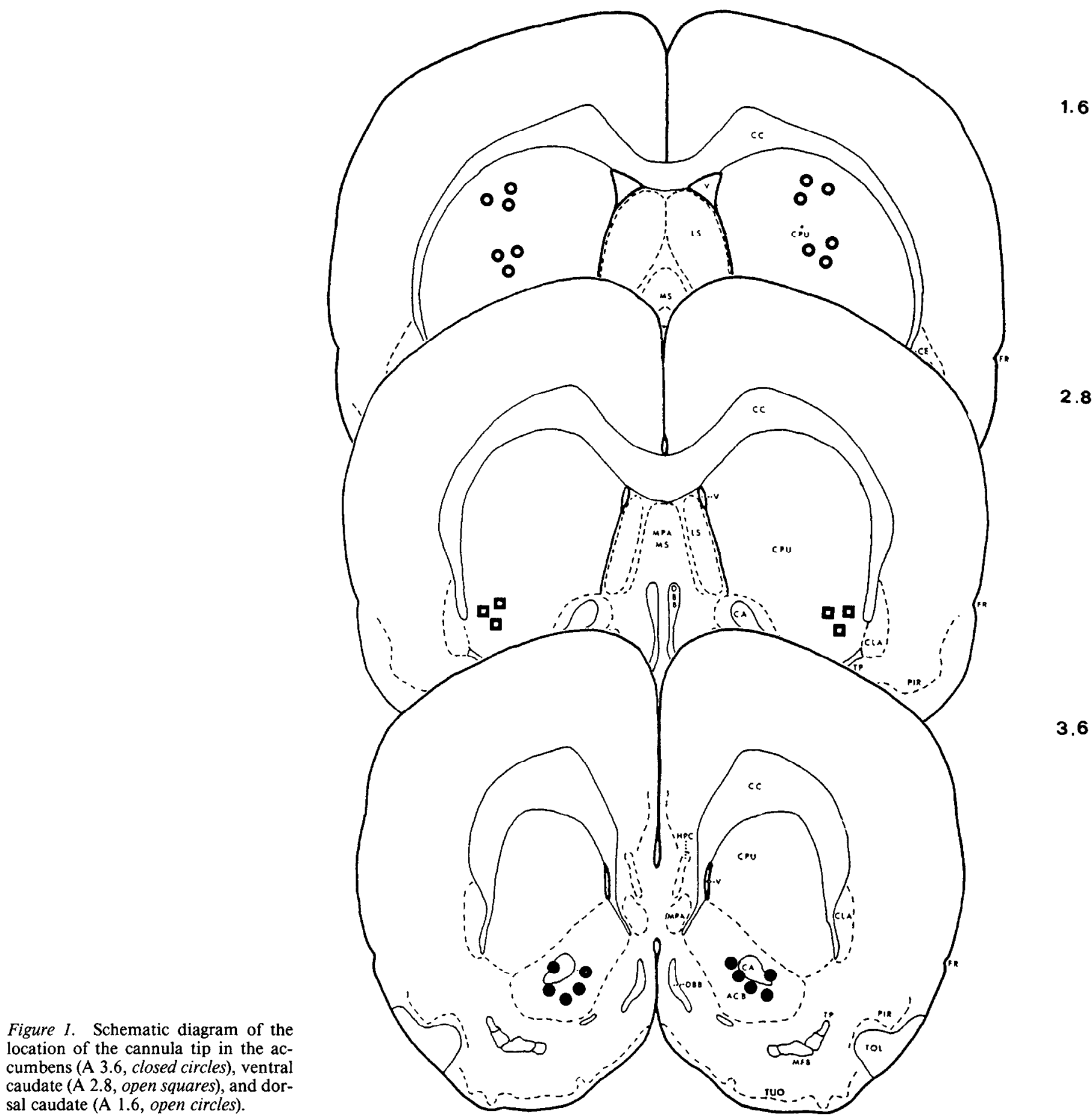

the cannulas were kept in place for additional 2 min to allow diffusion of the drugs.

Bchavioral testing. Two days after surgery, each rat was placed in a Perspex cage $(27 \times 42 \times 15 \mathrm{~cm})$ with a steel grid on the bottom and habituated for $60 \mathrm{~min}$. The bottoms of the cages were divided into four equal sectors. After the habituation period and while in the same cage, each animal was given a subcutaneous injection of saline or of drugs $15 \mathrm{~min}$ (naloxone, SCH 23390, raclopride, naltrindole) or $2 \mathrm{hr}$ (haloperidol) before bilateral intracerebral or intracerebroventricular injection. Behavior was videotaped, and the following behavioral categories were distinguished: 1 , horizontal locomotion associated with sniffing; 2 , rearing; 3, confined sniffing; 4 , licking of the floor; 5 , biting of the floor (gnawing); 6 , grooming. When rats showed immobility with frozen postures, they were tested for catalepsy by placing them on a vertical wire grid; an animal was considered cataleptic if it remained immobile on the grid for more than $20 \mathrm{sec}$. Locomotion was measured by counting the number of sectors entered by the rat with its forelegs. Rearing and grooming were measured in terms of number of items observed during periods of $10 \mathrm{~min}$. The other behavioral items were quantified in terms of percentage of time spent by the rat in performing each behavior during each 10 -min period. The behavior of each rat was observed continuously for $90 \mathrm{~min}$ after the intracerebral administration, and on videotapes only one behavioral item was analyzed at one time. Rats were used only once.

Dialysis. The rats were implanted under halothane anesthesia with a dialysis tube (AN-69 Hospal; 0.3-mm outer diameter) inserted trans- 

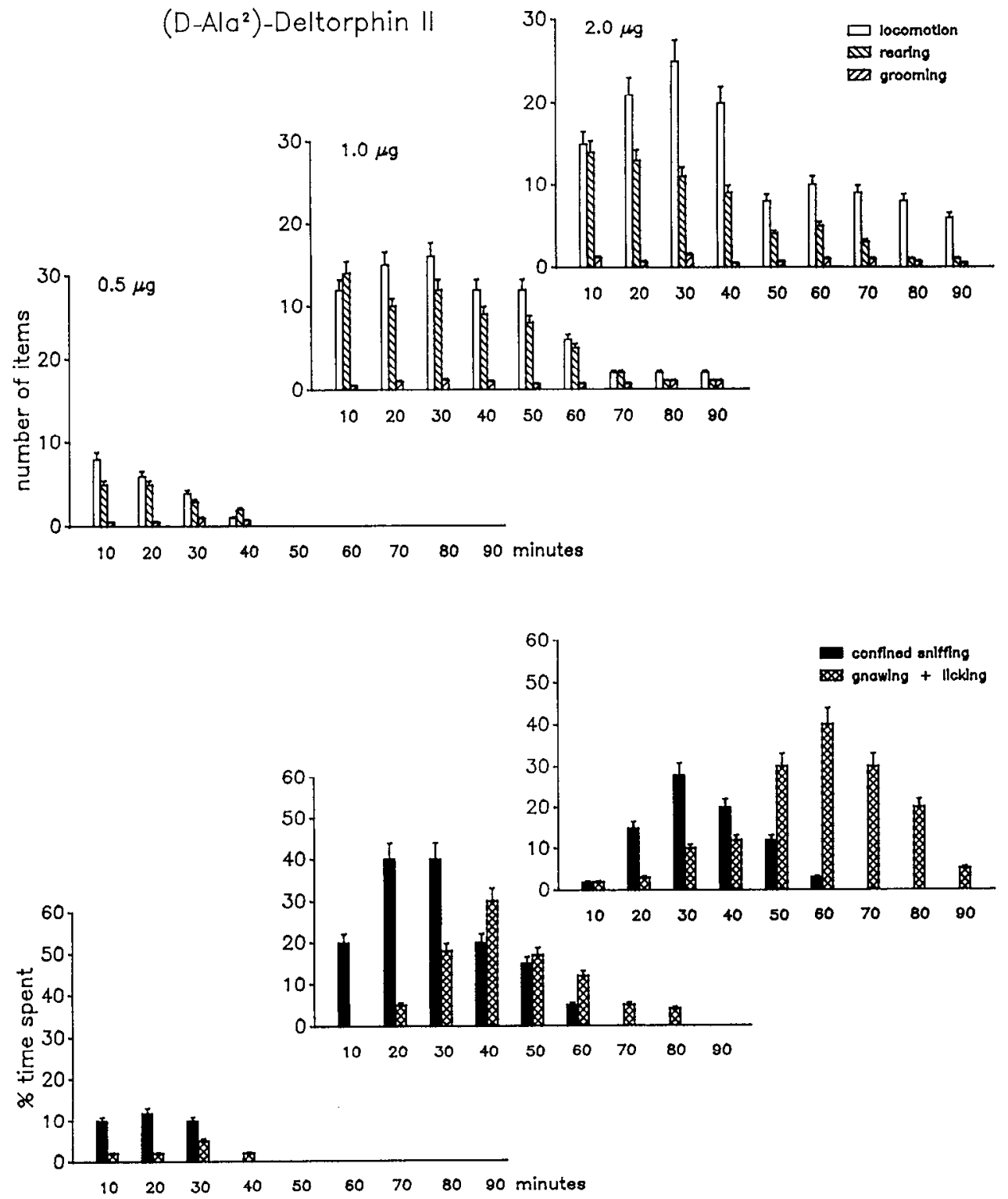

Figure 2. Quantitative behavioral effects of different doses of (D$\left.\mathrm{Ala}^{2}\right)$ deltorphin II $(0.5,1.0$, and $2.0 \mu \mathrm{g})$ injected bilaterally in the nucleus accumbens. Nonstereotyped items (locomotion, rearing, and grooming) were expressed as number of items performed every $10 \mathrm{~min}$. Stereotyped items (contined sniffing, gnawing/licking) were expressed as percent of the observation time $(10 \mathrm{~min})$ spent in performing each item. The data are means \pm SEM of the results obtained in at least 10 different animals for each dose.

versally through the dorsal caudate (coordinates: A, 7.4; V, 5.5), or through the nucleus accumbens (coordinates: A, 9.6; V, 7.0; Konig and Klippel, 1963).

The technique used to prepare and implant the dialysis probes was essentially that already described (Imperato and Di Chiara, 1984, 1985, 1986). Experiments were performed in freely moving rats $24 \mathrm{hr}$ after surgery. The Ringer's solution used for perfusing the dialysis fibers had the following composition: $147 \mathrm{~mm} \mathrm{NaCl}, 2.2 \mathrm{mM} \mathrm{CaCl}_{2}$, and $4.0 \mathrm{~mm}$ $\mathrm{KCl}$. Samples $(20 \mathrm{~min}, 40 \mu \mathrm{l})$ of dialysate were injected in a highperformance liquid chromatograph equipped with a reverse-phase ODS column (Supelcosil, Supelco Inc., Bellefonte, PA) and with an electrochemical detector (BAS, Lafayette, IN) in order to quantitate DA, dihydroxyphenylacetic (DOPAC), and homovanillic acid (HVA), according to the procedure already reported (Imperato and Di Chiara, 1984).

Histology. After behavioral testing, rats were given an overdose of Equithesin and perfused intracardially with saline followed by $10 \%$ formalin; the brains were removed, frozen, and sectioned in order to determine the locations of the cannulas (Fig. 1).

Drugs. The following drugs were used: (D-Ala ${ }^{2}$-deltorphin 11 (Tyr-DAla-Phe-Glu-Val-Val-Gly-NH ${ }^{2}$ ), SCH 23390 (kindly donated by Dr. E. Ongini, Essex, Italy), raclopride (ASTRA Lakemedel AB, Sodertalje, Sweden), PL017 (Peninsula Laboratories, CA), naloxone hydrochloride (Sigma Chemical Co., St. Louis, MO), and naltrindole (RBI, Natick,
MA). (D-Ala ${ }^{2}$ deitorphin II was obtained as previously reported (Erspamer et al., 1989). All drugs were dissolved in saline. Haloperidol solution (Serenase, Janssen) was diluted in distilled water.

Statistics. The data were analyzed by one-way ANOVA for repeated measures followed by Newman-Keuls multiple comparison test. Differences were considered as significant at $p<0.05$.

\section{Results}

Intra-accumbens ( $D$-Ala $\left.{ }^{2}\right)$ deltorphin II

The bilateral intra-accumbens administration of (D$\left.\mathrm{Ala}^{2}\right)$ deltorphin II (0.5-2.0 $\mu \mathrm{g}$ on each side) elicited a syndrome of pure behavioral stimulation characterized by locomotion (typically associated with sniffing), by rearing and grooming, and by stereotyped behavior with confined sniffing, gnawing, and licking (Fig. 2). The incidence of these behavioral items was dose related.

Locomotion increased after all the doses tested $(0.5,1$, and $2.0 \mu \mathrm{g}$, bilaterally); rearing and stereolypies (confined sniffing and licking/gnawing) reached a plateau at 1.0 and $2.0 \mu \mathrm{g}$; con- 


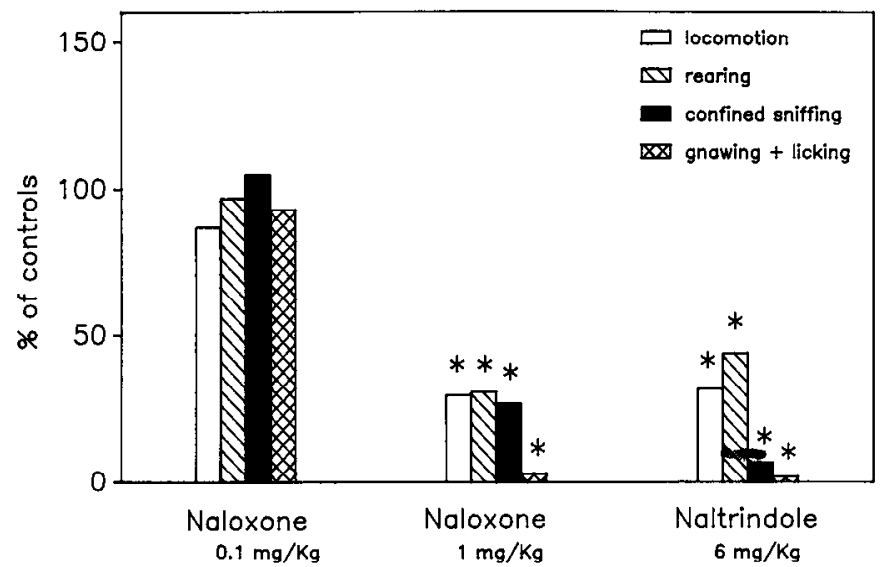

Figure 3. Effect of naloxone $(0.1$ or $1 \mathrm{mg} / \mathrm{kg}$, s.c.) and naltrindole $(6$ $\mathrm{mg} / \mathrm{kg}$, s.c.) on the behavioral syndrome elicited by $2 \mu \mathrm{g}\left(\mathrm{D}-\mathrm{Ala}^{2}\right)$ deltorphin II infused bilaterally in the accumbens $15 \mathrm{~min}$ after naloxone or naltrindole. Controls were administered saline subcutaneously $15 \mathrm{~min}$ before (D-Ala ${ }^{2}$ )deltorphin II. Data are means of the results obtained in five animals and are expressed as percent of the values obtained in controls. ${ }^{*}, P<0.05$ as compared to saline controls.

fined sniffing occupied the first half of the time course, while oral stereotypies (licking and gnawing) occupied the second half. Increasing the dose from 1 to $2 \mu \mathrm{g}$ resulted in a shift from lower(confined sniffing) to higher-intensity sterotypies (licking/gnawing).

As shown in Figure 3 and Table 1, rather high doses of naloxone $(1 \mathrm{mg} / \mathrm{kg}$, s.c.) were necessary to prevent the effects of 1 or $2 \mu \mathrm{g}$ (D-Ala ${ }^{2}$ )deltorphin II; lower doses of naloxone $(0.1 \mathrm{mg}$ / $\mathrm{kg}$, s.c.) were ineffective. Naltrindole $(6 \mathrm{mg} / \mathrm{kg}$, s.c.), a reportedly selective centrally acting nonpeptide $\delta$-antagonist (Portoghese et al., 1988), significantly reduced the deltorphin syndrome (Table 1, Fig. 3). The behavioral syndrome induced by intra-accumbens (D-Ala ${ }^{2}$ deltorphin II ( 1 or $2 \mu \mathrm{g}$, bilaterally) was prevented by low doses of the potent antagonist of $D_{1}$ receptors SCH 23390 ( 0.025 and $0.05 \mathrm{mg} / \mathrm{kg}$, s.c.; Fig. 4, Table 1) but not by cata-

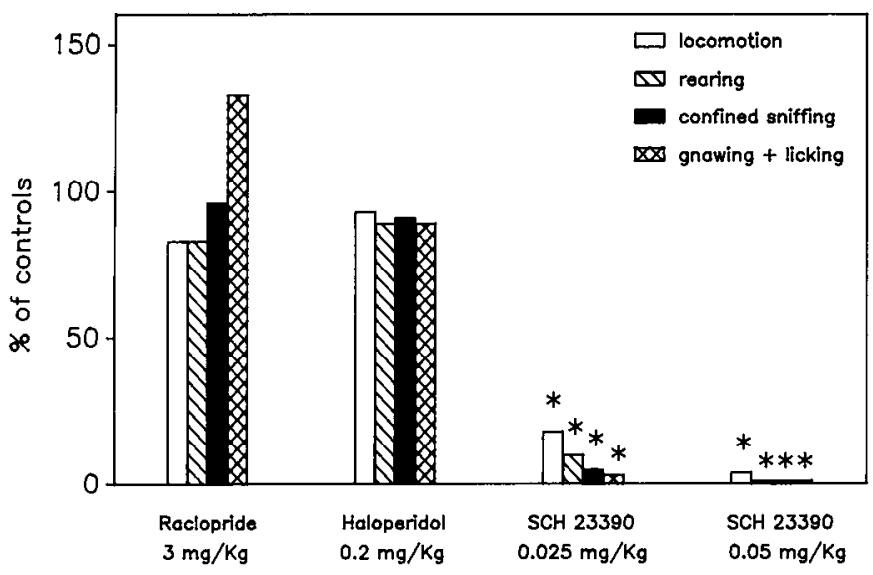

Figure 4. Effect of raclopride ( $3 \mathrm{mg} / \mathrm{kg}$, s.c.), haloperidol $(0.2 \mathrm{mg} / \mathrm{kg}$, s.c. $)$, and SCH $23390(0.025$ or $0.050 \mathrm{mg} / \mathrm{kg}$, s.c. $)$ on the behavioral effects of (D-Ala $\left.{ }^{2}\right)$ deltorphin II injected bilaterally in the accumbens 2 $\mathrm{hr}$ after haloperidol and $15 \mathrm{~min}$ after raclopride or SCH 23390 . Controls were administered saline subcutaneously $2 \mathrm{hr}$ or $15 \mathrm{~min}$ before (D$\mathrm{Ala}^{2}$ )deltorphin II. Data are means of the results obtained in five animals and are expressed as percent of the values obtained in controls. ${ }^{*}, P<$ 0.05 as compared to saline controls.

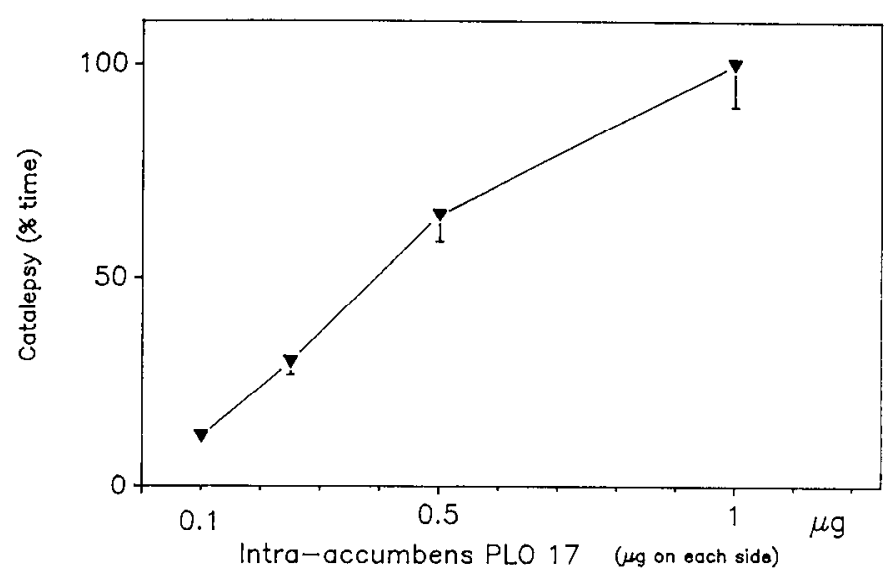

Figure 5. Dose-response curve for catalepsy induced by bilateral infusion in the accumbens of the $\mu$-agonist PL017. Data are means + SEM of the results obtained in five animals at each dose level.

leptogenic doses (Morelli and Di Chiara, 1985) of the preferential $\mathrm{D}_{2}$ antagonist haloperidol $(0.2 \mathrm{mg} / \mathrm{kg}$, s.c.; Fig. 4 , Table 1) or of the specific $D_{2}$ antagonist raclopride $(3.0 \mathrm{mg} / \mathrm{kg}$, s.c.; Hillegart and Ahlenius, 1987; Fig. 4, Table 1).

\section{Intracaudate (D-Ala $)^{2}$ deltorphin II}

As shown in Table 2, infusion of $0.5-2.0 \mu \mathrm{g}$ (D-Ala ${ }^{2}$ )deltorphin II in the dorsal or in the ventral caudate elicited behavioral effects not different from saline.

\section{Intra-accumbens PLO17}

In contrast with the $\delta$-agonist (D-Ala ${ }^{2}$ )deltorphin II, the selective peptidic $\mu$-agonist PL017 $(0.1-1 \mu \mathrm{g})$, infused bilaterally in the accumbens, elicited a syndrome of motor inhibition with rigidity and catalepsy whose duration was dependent from the dose administered (Fig. 5). The catalepsy was phenomenologically similar to neuroleptic catalepsy rather than to typical lead-pipe rigidity (see Di Chiara et al., 1979). No motor stimulation was observed during the $2 \mathrm{hr}$ of observation. Naloxone, in low doses $(0.1 \mathrm{mg} / \mathrm{kg}$, s.c. $)$, reversed the catalepsy induced by intra-accumbens PL017 (0.5 $\mu$ g bilaterally; Fig. 6). In contrast, the putative $\delta$-antagonist naltrindole $(6 \mathrm{mg} / \mathrm{kg}$, s.c.) failed to attenuate significantly the catalepsy elicited by $0.5 \mu \mathrm{g}$ PL017 in the accumbens (Fig. 6).

\section{Intracaudate PLO17}

PL017 $(0.5 \mu \mathrm{g})$ infused in the dorsal caudate induced only mild and short-lasting catalepsy and rigidity (not shown).

\section{Intracerebroventricular (D-Ala ${ }^{2}$ deltorphin II and PLOI7}

Opioids are known to exert biphasic effects after systemic or intracerebral administration (see introductory remarks). In order to evaluate the significance of the effects evoked by the peptides from the accumbens in terms of their overall central effects, we studied the behavioral effects of (D-Ala $\left.{ }^{2}\right)$ deltorphin II and of PL017 after intracerebroventricular administration.

Intracerebroventricular (D-Ala ${ }^{2}$ )deltorphin II (10 $\mu$ g; Fig. 7) elicited within minutes a dose-related motor activation qualitatively similar to but less intense than that obtained after intraaccumbens infusion of the same compound. Stereotyped items (confined sniffing, licking/gnawing) were present also after doses of $5 \mu \mathrm{g}$ bilaterally. 
Table 1. The effect of opioid antagonists and DA antagonists on behavioral effects of intra-accumbens (D-Ala ${ }^{2}$ )deltorphin II

\begin{tabular}{|c|c|c|c|c|c|}
\hline \multirow{3}{*}{$\begin{array}{l}\text { Treatment } \\
\text { (mg/kg, s.c.) }\end{array}$} & \multirow{2}{*}{\multicolumn{3}{|c|}{ Number/90 min }} & \multicolumn{2}{|c|}{ Percent time $/ 90 \mathrm{~min}$} \\
\hline & & & & \multirow{2}{*}{$\begin{array}{l}\text { Confined } \\
\text { sniffing }\end{array}$} & \multirow{2}{*}{$\begin{array}{l}\text { Gnawing/ } \\
\text { licking }\end{array}$} \\
\hline & Locomotion & Rearing & Grooming & & \\
\hline \multicolumn{6}{|c|}{ (D-Ala ${ }^{2}$ )deltorphin II, $1 \mu \mathrm{g}$ bilaterally } \\
\hline Saline $(15 \mathrm{~min})$ & $79.2 \pm 10$ & $62 \pm 8.3$ & $7.6 \pm 0.9$ & $15.1 \pm 2.0$ & $10.22 \pm 1.5$ \\
\hline Saline (120 min) & $72.3 \pm 6$ & $59 \pm 7$ & $8.1 \pm 0.5$ & $13.8 \pm 1.4$ & $11.5 \pm 1.7$ \\
\hline Naloxone, 0.1 & $67.4 \pm 8.3$ & $48.2 \pm 6.3$ & $5.8 \pm 0.8$ & $11.2 \pm 1.6$ & $9.8 \pm 1.4$ \\
\hline Naloxone, 1 & $9.6 \pm 1.2^{*}$ & $5.7 \pm 0.7^{*}$ & $2.8 \pm 0.3^{*}$ & $1.7 \pm 0.4^{*}$ & $0.4 \pm 0.2^{*}$ \\
\hline SCH $23390,0.05$ & $3.1 \pm 1.3^{*}$ & 0 & 0 & 0 & 0 \\
\hline SCH $23390,0.025$ & $14 \pm 1.5^{*}$ & $6.2 \pm 4.5^{*}$ & $2.2 \pm 0.6^{*}$ & $0.75 \pm 0.16^{*}$ & $0.32 \pm 0.7^{*}$ \\
\hline Haloperidol, 0.2 & $67.3 \pm 8.6^{\mathrm{NS}}$ & $53.7 \pm 9.3^{\mathrm{NS}}$ & $5.5 \pm 0.9^{\mathrm{Ns}}$ & $12.6 \pm 1.5^{\mathrm{NS}}$ & $10.2 \pm 1.6^{\mathrm{NS}}$ \\
\hline Raclopride, 3 & $65.9 \pm 8.2^{\mathrm{NS}}$ & $52.4 \pm 8.2^{\mathrm{NS}}$ & $5.2 \pm 0.7^{\mathrm{Ns}}$ & $14.5 \pm 1.8^{\mathrm{Ns}}$ & $13.6 \pm 1.9^{\mathrm{NS}}$ \\
\hline \multicolumn{6}{|c|}{ (DAla ${ }^{2}$ deltorphin II, $2 \mu \mathrm{g}$ bilaterally } \\
\hline Saline (15 min) & $125.6 \pm 18.6$ & $61.0 \pm 9.3$ & $9.0 \pm 0.5$ & $9.0 \pm 1.2$ & $16.9 \pm 1.8$ \\
\hline Saline $(120 \mathrm{~min})$ & $123.9 \pm 15.3$ & $65.3 \pm 5.8$ & $8.7 \pm 0.7$ & $10.2 \pm 0.8$ & $16.2 \pm 2$ \\
\hline Naloxone, 0.1 & $109.4 \pm 16.7$ & $59.5 \pm 8.5$ & $7.5 \pm 0.2$ & $9.5 \pm 1.3$ & $15.7 \pm 1.8$ \\
\hline Naloxone, 1 & $38.4 \pm 7.2^{*}$ & $19.2 \pm 2.0^{*}$ & $3.1 \pm 0.4^{*}$ & $2.5 \pm 0.4^{*}$ & $0.5 \pm 0.2^{*}$ \\
\hline Naltrindole, 6 & $40.2 \pm 5.3^{*}$ & $27.1 \pm 3.4^{*}$ & $4.0 \pm 0.1^{*}$ & $0.6 \pm 0.2^{*}$ & $0.3 \pm 0.08^{*}$ \\
\hline $\mathrm{SCH} 23390,0.05$ & $6.2 \pm 1.0^{*}$ & $1.1 \pm 0.1^{*}$ & 0 & 0 & 0 \\
\hline Haloperidol, 0.2 & $122.5 \pm 16^{\mathrm{NS}}$ & $64.3 \pm 9.5^{\mathrm{NS}}$ & $9.7 \pm 1.3^{\mathrm{NS}}$ & $12.3 \pm 1.4^{\mathrm{Ns}}$ & $20.3 \pm 3.3^{\mathrm{NS}}$ \\
\hline Raclopride, 3 & $120.8 \pm 18^{\mathrm{NS}}$ & $54.7 \pm 9.6^{\mathrm{NS}}$ & $7.1 \pm 1.0^{\mathrm{Ns}}$ & $11.3 \pm 1.6^{\mathrm{Ns}}$ & $17.3 \pm 2.8^{\mathrm{Ns}}$ \\
\hline
\end{tabular}

$N=5$; values are means \pm SEM. Animals were pretreated with subcutaneous saline, naloxone, SCH 23390 , or raclopride 15 min before and with saline or haloperidol 120 min before. ${ }^{*}$, significantly different from saline $(P<0.05)$; NS, not significantly different from saline $(P<0.05)$.

Intracerebroventricular (D-Ala ${ }^{2}$ )deltorphin II-induced stereotypy was prevented by subcutaneous doses of naloxone as high as $1.0 \mathrm{mg} / \mathrm{kg}$ (Fig. 7); lower doses $(0.1 \mathrm{mg} / \mathrm{kg}$ ) were ineffective (not shown). The $\mathrm{D}_{1}$ antagonist $\mathrm{SCH} 23390(0.05 \mathrm{mg} / \mathrm{kg}$, s.c.) completely prevented the behavioral stimulation and the stereotypies elicited by intracerebroventricular (D-Ala $\left.{ }^{2}\right)$ deltorphin II (Fig. 7). Intracerebroventricular PL017 (5 $\mu \mathrm{g}$ ) elicited a catalepsy syndrome indistinguishable from that elicited by this compound after intra-accumbens infusion (Fig. 8). Low doses of systemic naloxone $(0.1 \mathrm{mg} / \mathrm{kg}$, s.c.) prevented intracerebroventricular PL017-induced catalepsy (Fig. 8).

\section{Intra-accumbens and intracaudate saline}

As shown in Table 2, intra-accumbens or intracaudate saline resulted only in mild, short-lasting motor activation related to the arousing effects of the manipulations involved in the local injection procedure.

\section{Brain dialysis}

In freely moving rats implanted with dialysis probes in the accumbens, (D-Ala ${ }^{2}$ )deltorphin II, added to the Ringer's solution, stimulated DA release in a concentration-dependent manner (threshold, $5 \mu \mathrm{M}$; maximal, $50 \mu \mathrm{M}$; maximum increase over basal, $+120 \%$; Fig. $9 \mathrm{~A}$ ). During the application of the highest concentration of (D-Ala $\left.{ }^{2}\right)$ deltorphin II $(50 \mu \mathrm{M})$, a syndrome of motor stimulation was observed similar to that evoked by intraaccumbens injection of the same compound.

No changes in DA release and behavior were observed after reverse dialysis of $\mathrm{D}-\mathrm{Ala}^{2}$ )deltorphin $\mathrm{II}$ in the dorsal caudate (Fig. 9B)

Table 2. The effect of intra-accumbens and intracaudate injection of saline and (D-Ala $\left.\mathrm{a}^{2}\right)$ deltorphin II $(2 \mu \mathrm{g})$

\begin{tabular}{|c|c|c|c|c|c|}
\hline \multirow{3}{*}{$\begin{array}{l}\text { Injection site } \\
\text { and treatment }\end{array}$} & \multirow{2}{*}{\multicolumn{2}{|c|}{ Number/90 min }} & \multicolumn{3}{|c|}{ Percent time $/ 90 \mathrm{~min}$} \\
\hline & & & \multirow[b]{2}{*}{ Grooming } & \multirow{2}{*}{$\begin{array}{l}\text { Confined } \\
\text { sniffing }\end{array}$} & \multirow{2}{*}{$\begin{array}{l}\text { Gnawing/ } \\
\text { licking }\end{array}$} \\
\hline & Locomotion & Rearing & & & \\
\hline \multicolumn{6}{|l|}{ Nucleus accumbens } \\
\hline Saline & $3 \pm 1.22$ & $2.2 \pm 0.66$ & $3.4 \pm 1.29$ & 0 & 0 \\
\hline \multicolumn{6}{|l|}{ Dorsal caudate } \\
\hline Saline & $4.4 \pm 1.57$ & $2.6 \pm 0.81$ & $2.8 \pm 0.66$ & 0 & 0 \\
\hline Deltorphin $(2 \mu \mathrm{g})$ & $3.0 \pm 1.033$ & $3.83 \pm 1.22$ & $3.33 \pm 1.05$ & 0 & 0 \\
\hline \multicolumn{6}{|l|}{ Ventral caudate } \\
\hline Saline & $4.6 \pm 0.92$ & $3.4 \pm 1.07$ & $2.4 \pm 0.51$ & 0 & 0 \\
\hline Deltorphin $(2 \mu \mathrm{g})$ & $5 \pm 1.58$ & $3.8 \pm 0.86$ & $2.2 \pm 1.02$ & 0 & 0 \\
\hline
\end{tabular}

$N=5 ;$ values are means $\pm \mathrm{SEM}$. 
Figure 6. Effect of naloxone $(0.1 \mathrm{mg} /$ $\mathbf{k g}$, s.c., $15 \mathrm{~min}$ before) and naltrindole $(6 \mathrm{mg} / \mathrm{kg}, \mathrm{s.c}$.$) on the catalepsy induced$ by bilateral infusion of PLO17 $(0.5 \mu \mathrm{g})$ in the accumbens. Controls were administered saline subcutaneously 15 min before PL017. Data are means \pm SEM of the results obtained in five animals. ${ }^{*}, P<0.05$ as compared to saline controls.

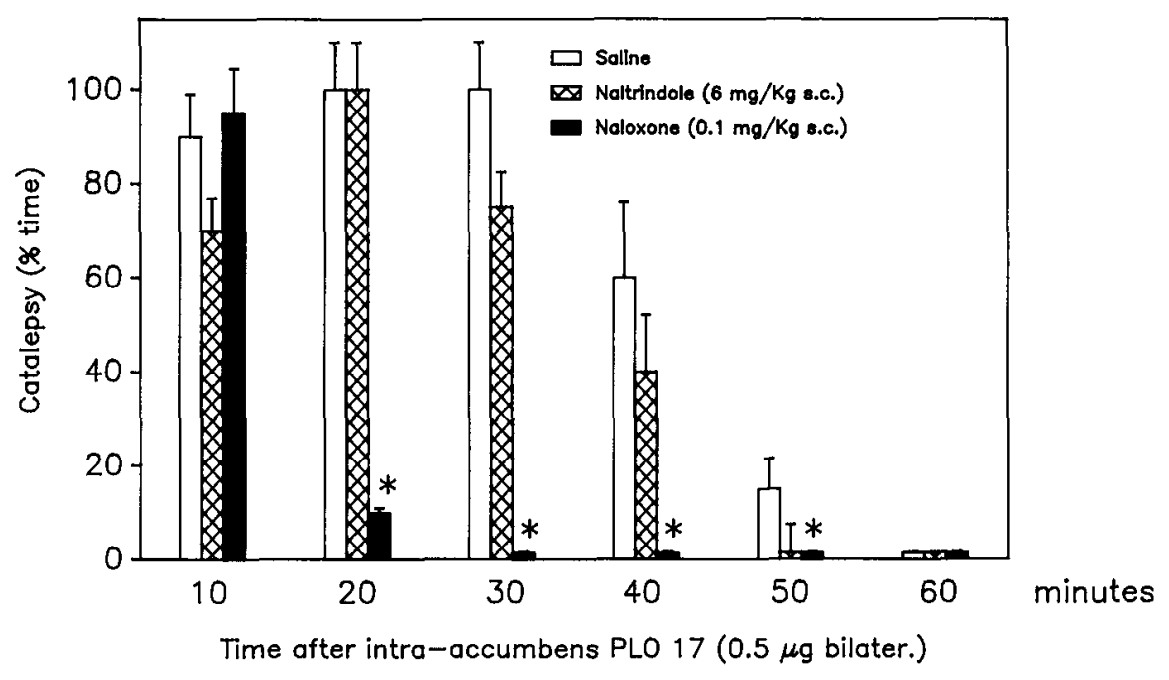

Systemic administration of naloxone ( $1 \mathrm{mg} / \mathrm{kg}$, s.c.) prevented the stimulation of DA output and motor activity evoked by dialysis with $50 \mu \mathrm{M}\left(\mathrm{D}-\mathrm{Ala}^{2}\right)$ deltorphin II in the accumbens (Fig. 10). Intra-accumbens dialysis of PL017 $(50 \mu \mathrm{M})$ failed to modify the output of DA and of its metabolites (Fig. 11A) in spite of its ability to induce catalepsy. Intra-caudate dialysis of PLO17 $(50 \mu \mathrm{M})$ was ineffective on DA output and on behavior (Fig. $11 B)$.

\section{Discussion}

(D-Ala ${ }^{2}$ deltorphin II is a highly specific and potent agonist of $\delta$-opioid receptors (Erspamer et al., 1989). Thus, in binding studies, (D-Ala ${ }^{2}$ )deltorphin II has been found to have an affinity for $\delta$-receptors at least 3000 times higher that for $\mu$-receptors; in the same experiments, D-Pen, D-Pen enkephalin was about 10 times less selective (Erspamer et al., 1989). On isolated organs, (D-Ala ${ }^{2}$ )deltorphin II showed a potency in eliciting $\delta$-actions at least 10,000 times higher than that required for evoking $\mu$-actions (Erspamer et al., 1989). PL017, on the other hand, shows quite high selectivity and potency for $\mu$-receptors (Blanchard et al., 1987). An additional characteristic of these compounds is their metabolic stability, which derives from the presence of a strategically placed $\mathrm{D}$-amino acid in the peptide chain (Chang et al., 1976, 1983).

The present study demonstrates intense (stereotyped), topographically discrete (restricted to the accumbens), and receptorspecific motor stimulation after intracerebral infusion of (D-Ala ${ }^{2}$ deltorphin II. Sterotypies similar to those elicited by intra-accumbens ( $\left.\mathrm{D}-\mathrm{Ala}^{2}\right)$ dcltorphin II and characterized by confined sniffing, licking, and gnawing are typically obtained by stimulation of dopaminergic receptors (Longoni et al., 1987b). The motor stimulation previously reported after intra-accumbens infusion of nonspecific opioid peptides such as (D-Ala ${ }^{2}-\mathrm{D}-$ Leu ${ }^{5}$ )enkephalin (DADLE; Pert and Sivit, 1977; Kalivas et al., 1983) was characterized by locomotor stimulation without stereotypy and therefore appears mild in comparison with that observed in the present study after (D-Ala $\left.{ }^{2}\right)$ deltorphin II. This might be due in part to residual activity of DADLE at $\mu$-receptors, whose stimulation, by inhibiting motor activity (see below), might have prevented the full expression of the behavioral stimulant effect of $\delta$-receptor stimulation. This suggestion is supported by the fact that the locomotor stimulation induced by intra-accumbens DADLE is generally preceded by catalepsy, which is likely to be a $\mu$-effect (see below).

The sensitivity of $\left(\mathrm{D}-\mathrm{Ala}^{2}\right)$ deltorphin II effects to blockade by naltrindole (Portoghese et al., 1988) and by 1.0 but not by 0.1 $\mathrm{mg} / \mathrm{kg}$ naloxone is consistent with its $\delta$ nature (Yoshimura et al., 1982).

The motor-stimulant effects of intra-accumbens (DAla ${ }^{2}$ )deltorphin II, like those of DADLE (Pert and Sivit, 1977; Kalivas et al., 1983), were not significantly reduced by haloperidol; in contrast, $\mathrm{SCH} 23390$, a specific $\mathrm{D}_{1}$ antagonist (Hyttel, 1983), completely prevented the entire behavioral syndrome induced by intra-accumbens (D-Ala $\left.{ }^{2}\right)$ deltorphin II. If one considers that haloperidol is a preferential $\mathrm{D}_{2}$ antagonist (Seeman, 1980), the most parsimonious explanation of the differential effect of SCH 23390 and haloperidol on (D-Ala ${ }^{2}$ )deltorphin II effects is that they are mediated by DA acting specifically on $D_{1}$ receptors. In agreement with this, the present study shows that raclopride, a specific $\mathrm{D}_{2}$ antagonist (Ogren et al., 1986), fails to modify the deltorphin syndrome. On the other hand, our study also shows that intra-accumbens dialysis of $\left(\mathrm{D}-\mathrm{Ala}^{2}\right)$ deltorphin II stimulates DA release in the accumbens. Stimulation of DA release by intra-accumbens (D-Ala ${ }^{2}$ deltorphin II might take place through presynaptic stimulatory $\delta$-receptors; it is puzzling, however, that such receptors have been shown in the caudate but not in the accumbens (Lubetzki et al., 1982; Petit et al., 1986).

Deltorphin-induced behavioral stimulation appears mediated specifically by $D_{1}$ receptors in the accumbens. Indeed, the motor effects of $\left(\mathrm{D}-\mathrm{Ala}^{2}\right)$ deltorphin II are not the only example of a mesolimbic DA-mediated response showing preferential blockade by the $D_{1}$ antagonist SCH 23390 . In fact, high sensitivity to SCH 23390 is also observed for the motor-stimulant effects of systemic morphine (Longoni et al., 1987a; Pollock and Kornetsky, 1989). One explanation of these findings is that in the mesolimbic DA system the true synaptic receptor for DA is the $D_{1}$ receptor, while $D_{2}$ receptors might be nonsynaptic receptors activated by excess DA released from nerve terminals or by exogenous $\mathrm{D}_{2}$ agonists. An alternative explanation would be that stimulation of $\delta$-receptors by (D-Ala ${ }^{2}$ )deltorphin II specifically potentiates $D_{1}$-mediated responses and that stereotypies arise from the combined action of stimulation of $D_{1}$ receptors by deltorphin-induced release of DA and stimulation of $\delta$-receptors. 

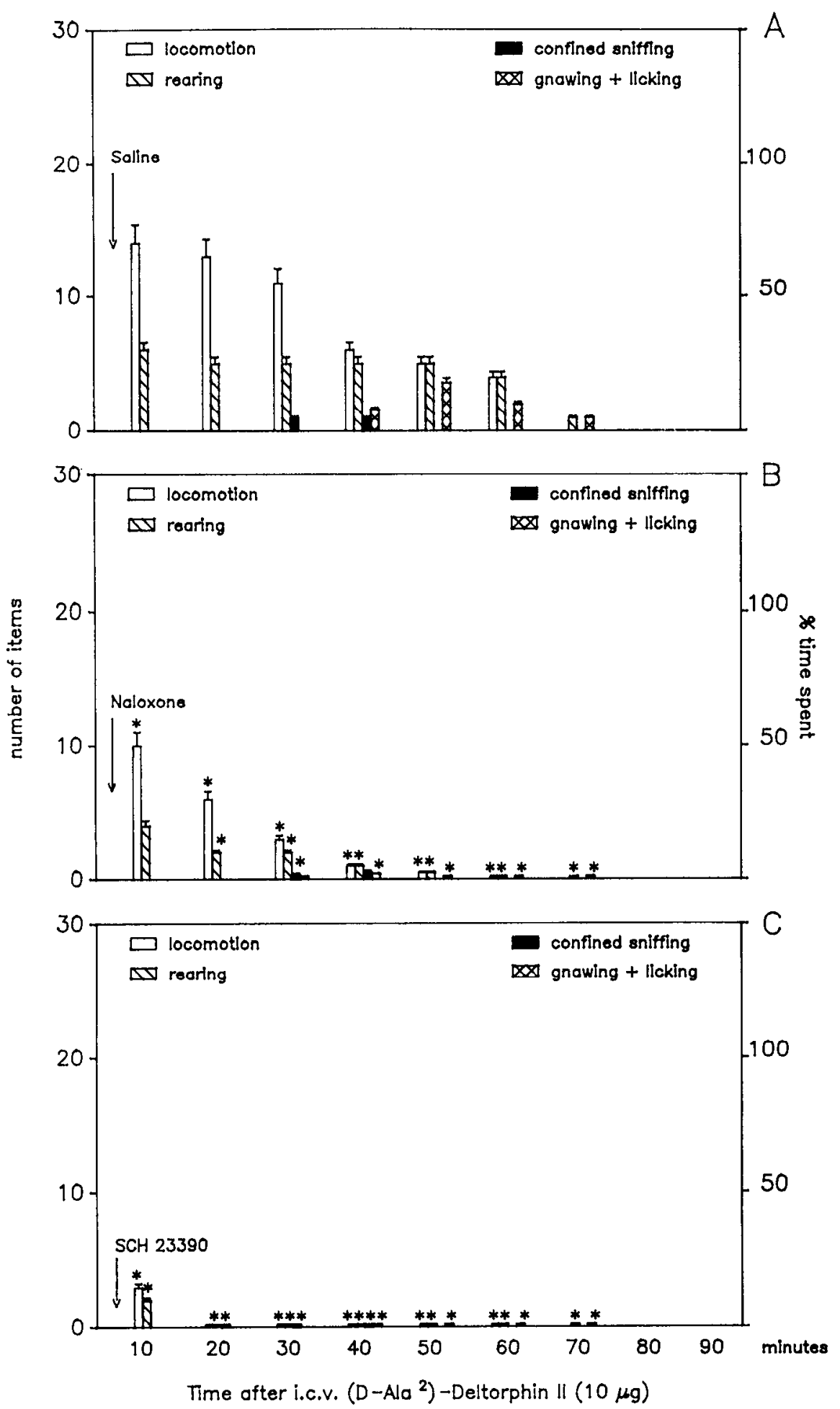

Figure 7. Behavioral effects of the intracerebroventricular administration of (D-Ala ${ }^{2}$ )deltorphin II and its interaction with naloxone $(1 \mathrm{mg} / \mathrm{kg}$, s.c.) and with SCH $23390(0.05 \mathrm{mg} / \mathrm{kg}$, s.c. $)$ given 15 min before. Data are means \pm SEM of the results obtained in five animals. *, $P<0.05$ as compared to deltorphin alone.
The results obtained with intra-accumbens (D-Ala ${ }^{2}$ )deltorphin II suggest a revision of the concept that opioids exert DA-dependent behavioral stimulation from the ventral tegmentum and DA-independent stimulation from the nucleus accumbens (Kalivas et al., 1983). This conclusion was based on the differential sensitivity to haloperidol of the effects of intrategmental as compared to intra-accumbens DADLE. By analogy with (D$\mathrm{Ala}^{2}$ )deltorphin II, we now suggest that the stimulant effects of intra-accumbens DADLE are also dopaminergic but are me- diated by $D_{1}$ receptors. Studies are in progress in order to confirm this suggestion.

Intra-accumbens or intracerebroventricular infusion of the $\mu$-opioid peptide PL017 resulted in a behavioral syndrome quite opposite to that evoked by (D-Ala ${ }^{2}$ )deltorphin II. Thus, PL017 evoked a syndrome of motor inhibition and catalepsy sensitive to low doses of naloxone $(0.1 \mathrm{mg} / \mathrm{kg}$, s.c.) but not to naltrindole; this syndrome was reminiscent of the catalepsy elicited by neuroleptics (DA receptor blockers) rather than of the lead-pipe 
Figure 8. Catalepsy after intracerebroventricular administration of PL017 $(5 \mu \mathrm{g})$ and the effect of naloxone $(0.1$ $\mathrm{mg} / \mathrm{kg}$, s.c.) given $15 \mathrm{~min}$ before. Data are means \pm SEM of the results obtained in five animals. ${ }^{*}, P<0.05$ as compared to saline controls.
Figure 9. Effect of reverse dialysis of $\left(D-A^{2}\right)$ deltorphin II $(50 \mu \mathrm{M}$ in the accumbens and in the dorsal caudate) on the output of DA, DOPAC, and HVA in dialysates. Basal values (expressed in $\mathrm{pmol} / \mathrm{sample}$ ) in the nucleus accumbens and in the dorsal caudate, respectively, were as follows: $D A, 0.23 \pm 0.03$, $0.45 \pm 0.06 ; D O P A C, 24.6 \pm 3,45 \pm$ 5; $H V A, 17 \pm 1.5,38.8 \pm 3.2$. Data are means \pm SEM of the results obtained in five animals expressed as percent of basal values. ${ }^{*}, P<0.05$ as compared to basal values.

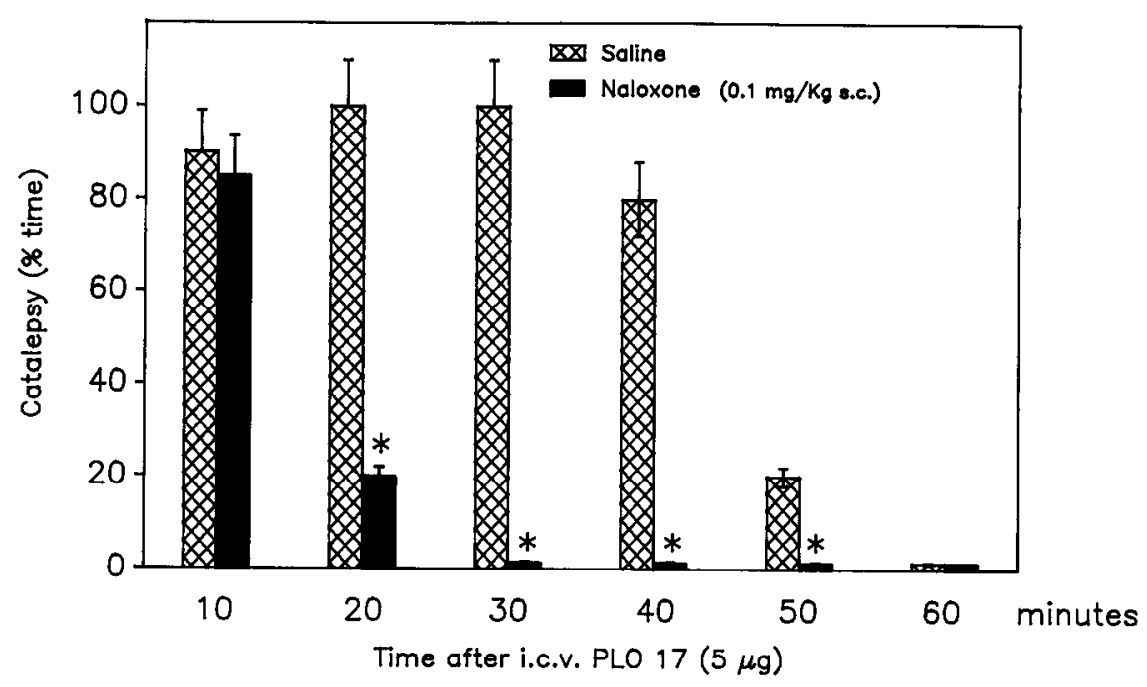

A
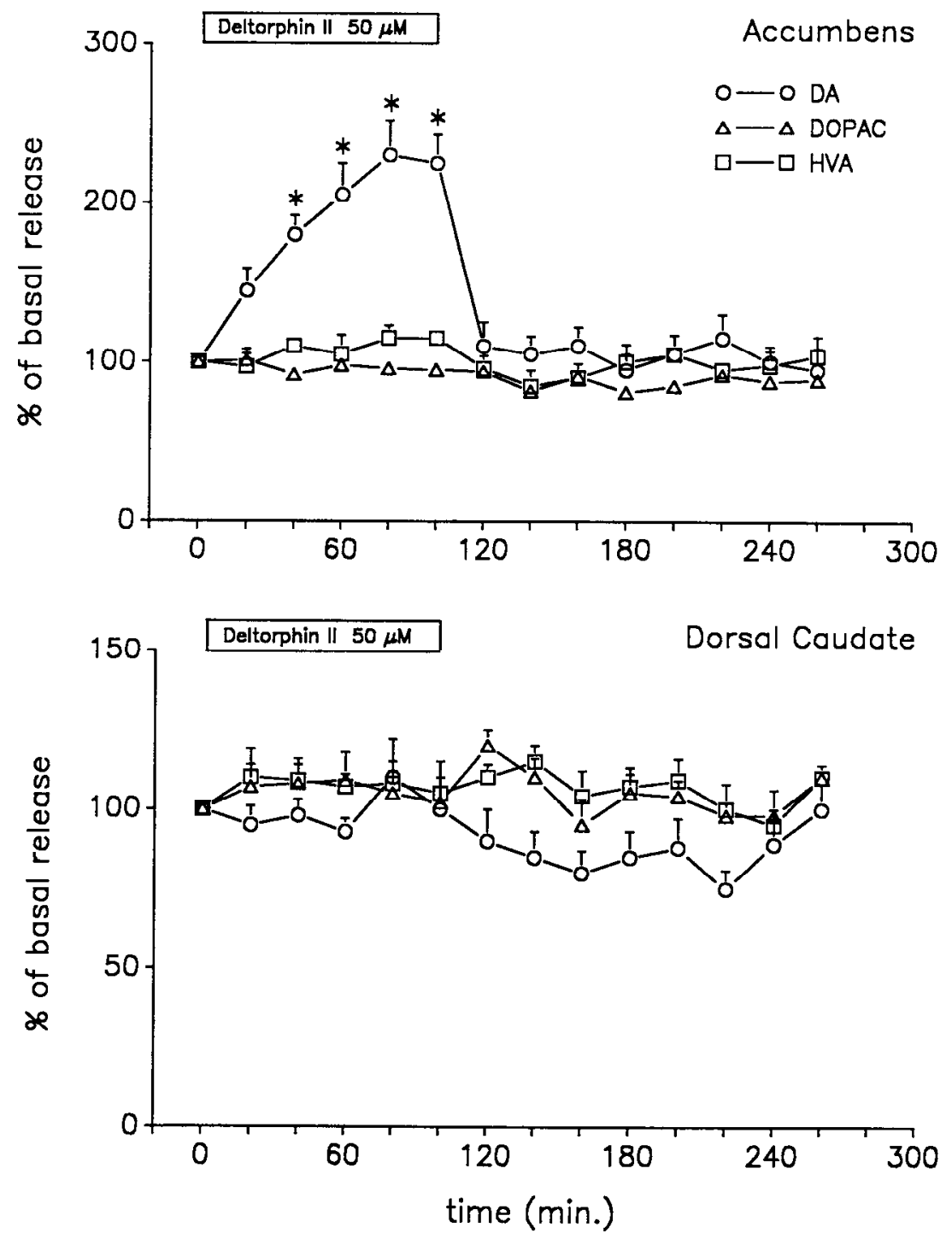


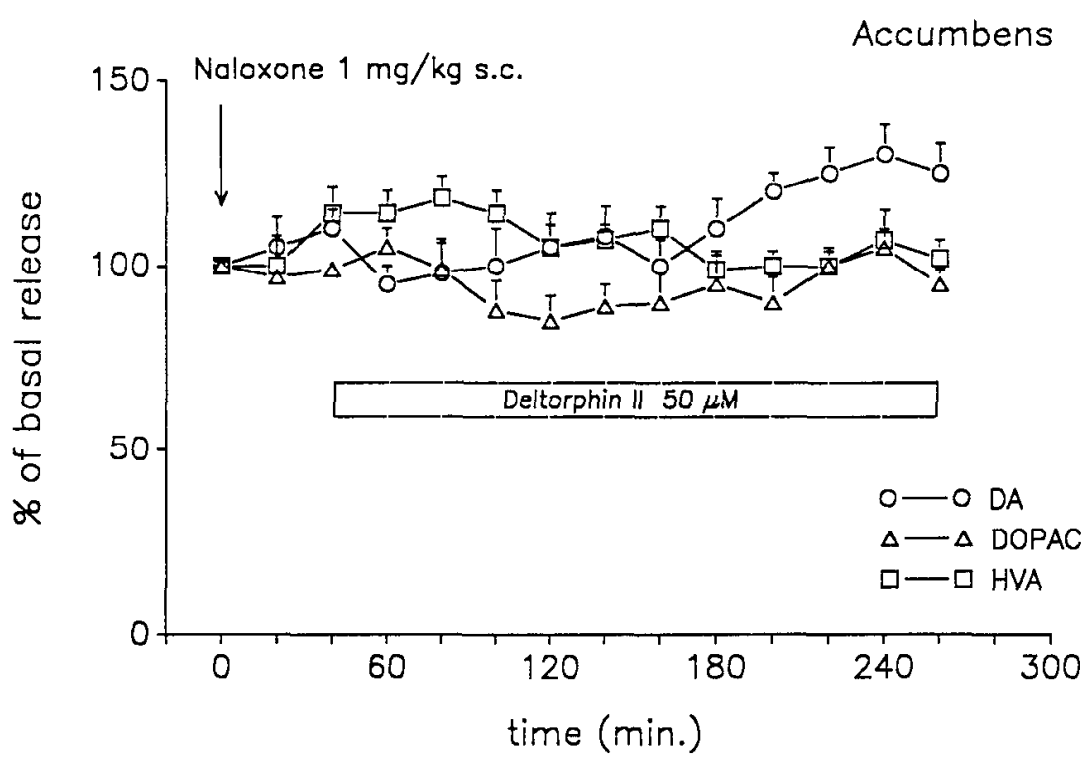

Figure 10. Effect of systemic naloxone $(1 \mathrm{mg} / \mathrm{kg}, \mathrm{s.c}$.) on the effect of (DAla $\left.{ }^{2}\right)$ deltorphin II $(50 \mu \mathrm{M})$ on the output of DA and metabolites in the accumbens. Basal values (in pmol/sample) in the nucleus accumbens and in the dorsal caudate, respectively, were as follows: $D A, 0.32 \pm 0.03,0.45 \pm 0.05$ DOPAC, $26.7 \pm 3,53 \pm 6 ; H V A, 18$ $\pm 2.0,37.5 \pm 3.5$. Data are means \pm SEM of the results obtained in five rats. catalepsy clicited by systemic morphinc-like opiates (sce $\mathrm{Di}$ Chiara et al., 1979, for discussion of this issue). However, apart from this apparent relationship with DA, local application of PL017 by accumbens dialysis failed to modify DA release, indicating that the behavioral effects of PL017 are not due to a presynaptic interference with DA transmission, but eventually to a modulatory action of $\mu$-receptors on the effects of stimulation of postsynaptic DA receptors. In fact, recent results show that stimulation of $\mu$-receptors reduces the stimulatory action of $D_{1}$ receptor activation on cAMP production (Groppetti et al., 1990).

The observation of clearcut differential effects of $\delta$-versus $\mu$-receptor stimulation in the accumbens provides strong behavioral and biochemical evidence for separate functions of $\mu$ and $\delta$-receptors in specific brain areas. In the accumbens, a morphological substrate of such differential behavioral effects might be the differential distribution of opioid receptors, as demonstrated by receptor autoradiography; this distribution is diffuse for $\delta$ - and patchy for $\mu$-receptors (Mansour et al., 1988).

The accumbens appears to be a specific site of origin of the central motor effects of $\mu$ - or $\delta$-opioid receptor stimulation, because no motor effects were obtained from dorsal or ventral caudate administration of PLO17 or (D-Ala ${ }^{2}$ )deltorphin II. Indeed, the lack of responses from the caudate is surprising in view of the fact that this area contains high concentrations of $\mu$ - as well as $\delta$-receptors and that the presence of $\delta$-receptors stimulating DA release has been shown in this area rather than in accumbens (Lubetzki et al., 1982). Failure to obtain behavioral responses after intracaudate administration of opioid peptides might be due to the fact that the area to be influenced for obtaining an effect is larger than that which can be reached by diffusion by relatively polar compounds such as the peptides. Alternatively, the responsive area in the caudate is quite small, and we simply failed to hit the right spot (Kelley et al., 1988).

If indeed, as indicated by the present study, the motor-stimulant effects of intra-accumbens opioid peptides are mediated by $\delta$-receptors, it is unlikely that the motor-stimulant effects of systemic morphine-like opiates, which are $\mathrm{mu}$ in nature, are due to a direct action on the accumbens as suggested by Amalric and Koob (1985). In fact, as shown by the rcsults obtained in the present study with PL017, an action of morphine in the accumbens would rather result in catalepsy. The motor-stimulant effects of systemic morphine are more likely to be due to stimulation of $\mu$-receptors in the ventral tegmentum area (VTA)medial substantia nigra (SN), resulting in disinhibition of DA neurons projecting to the accumbens (Di Chiara and Imperato, 1988b; Morelli et al., 1989).

It is interesting, therefore, that while both $\mu$ - and $\delta$-opioids can stimulate DA transmission in the mesolimbic DA system and produce behavioral activation, the mechanism of these effects is different for the two types of opioid receptors, taking place proximally (i.e., in the SN-VTA region) in the case of $\mu$-opiates and distally (i.e., in limbic terminal DA regions) in the case of $\delta$-opioids.

The present results are in contrast with the notion that oral stereotypies arise from the caudate rather than from the accumbens (Creese and Iversen, 1975); indeed, this conclusion derives from studies performed with amphetamine, whose effects, in contrast with those of $\left(\mathrm{D}-\mathrm{Ala}^{2}\right)$ deltorphin II, are blocked not only by $\mathrm{D}_{1}$ but also by $\mathrm{D}_{2}$ antagonists (Creese and Iversen, 1975). The differential sensitivity of amphetamine and (DAla ${ }^{2}$ )deltorphin II to $\mathrm{D}_{2}$ antagonism indicates that the population of DA receptors stimulated by amphetamine is different from that stimulated following intra-accumbens deltorphin. This in turn might be the basis for the ability of ( $\left.\mathrm{D}-\mathrm{Ala}^{2}\right)$ deltorphin II, in contrast with amphetamine, to elicit oral stereotypies from the accumbens. In this respect, it is notable that (D$\mathrm{Ala}^{2}$ )deltorphin II is capable of eliciting $\mathrm{D}_{1}$-dependent oral stereotypies even under strong blockade of $D_{2}$ receptors by raclopride or by haloperidol. This would imply that, under $\delta$-receptor stimulation, concurrent $\mathrm{D}_{1}$ and $\mathrm{D}_{2}$ stimulation (Longoni et al., 1987b) is not essential for the expression of oral stercotypies. A reason for this might be that delta-receptor stimulation strongly potentiates the effect of $D_{1}$ receptor stimulation by DA released by deltorphin.

The observation of the present study that $\delta$-receptors exert a powerful facilitatory influence on dopaminergic transmission in the accumbens might have far-reaching consequences. In fact, 
Figure 11. Effect of PL017 $(50 \mu \mathrm{M})$, applied by reverse dialysis, on the output of DA and metabolites in the accumbens and in the dorsal caudate as estimated by transcerebral dialysis in freely moving rats. Basal values (in $\mathrm{pmol} / \mathrm{sample}$ ) in the nucleus accumbens and in the dorsal caudate, respectively, were as follows: $D A, 0.35 \pm 0.04$ $0.05 \pm 0.05 ; D O P A C, 23.6 \pm 5,54 \pm$ $5 ; H V A, 16 \pm 2,35 \pm 4$. Data are means \pm SEM of the results obtained in five rats.
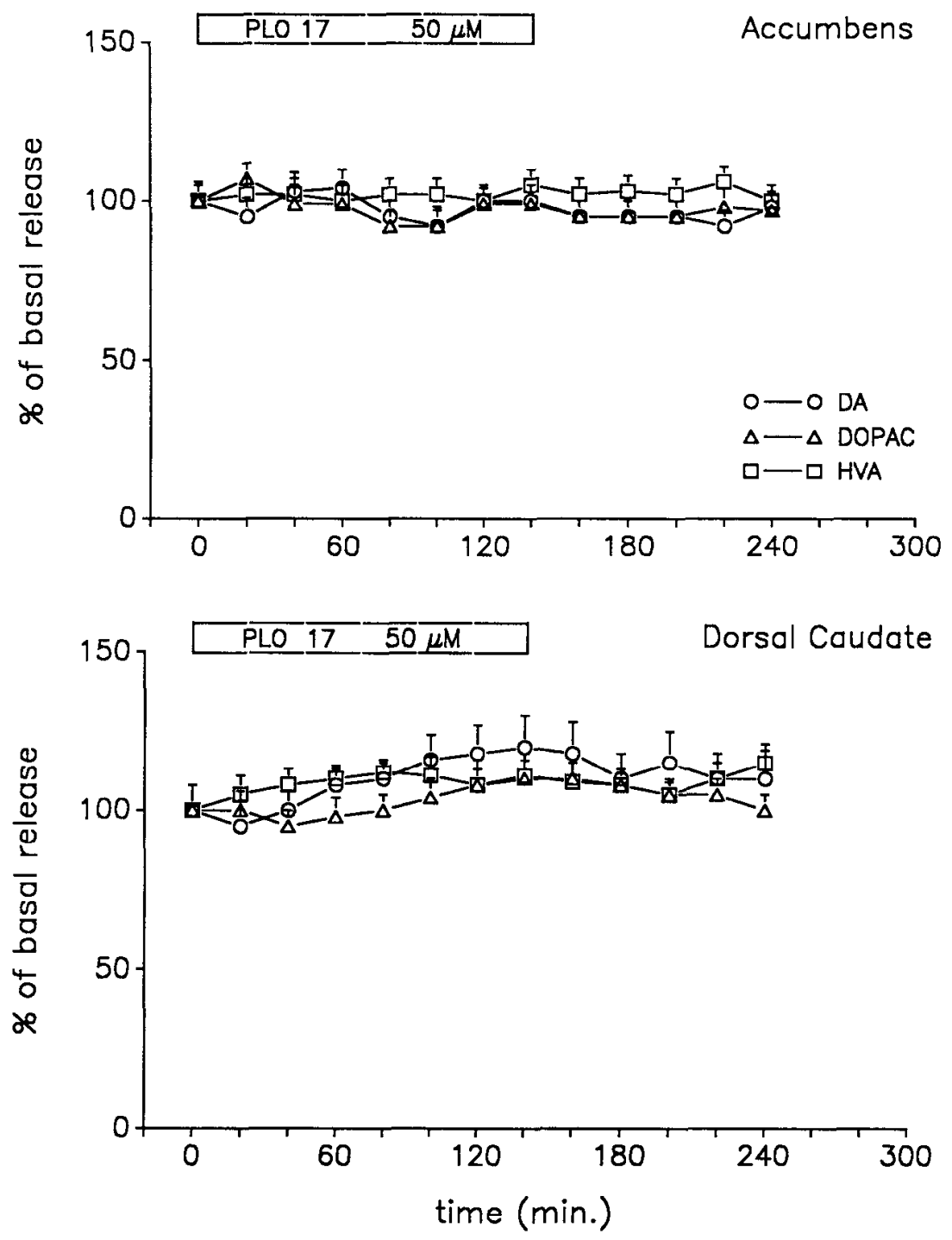

$\mathbf{B}$

the mesolimbic dopamine system (which includes as a major terminal area the accumbens) is currently regarded as an interface for the conversion of motivation into action (Mogenson et al., 1980). In particular, stimulation of DA transmission is regarded as a major factor in the rewarding properties of various stimuli, including natural reinforcers (food, sex) and drugs of abuse (Wise and Rompré, 1989); $\delta$-receptors, on the other hand, have been shown to exert DA-dependent rewarding effects (Shippenberg et al., 1987). Given these premises, an interaction like the one reported in the present study might provide a possible neurochemical basis for the postulated role of the limbic system in normal and abnormal behavior (Stevens, 1973).

To summarize, a number of conclusions can be drawn from the present study. First, $\delta$-receptors in the accumbens exert a powerful stimulant influence on DA transmission consisting of stimulation of DA release and resulting in typical stereotyped behavior.

Second, $\mu$-receptors in the accumbens elicit a powerful inhib- itory influcnce on motor activity (catalcpsy), which appears independent from changes in DA release. Therefore, at least for motor behavior, the actions of $\mu$ - and $\delta$-receptor stimulation can be clearly separated; this shows that the two receptors can be distinguished not only at the recognition site but also at the behavioral level.

Third, the motor stimulant effects of intra-accumbens (DAla ${ }^{2}$ )deltorphin II are specifically mediated by $D_{1}$ receptors. Because these effects appear to be due to a stimulation of DA release in the accumbens, the results suggest that $D_{1}$ rather than $D_{2}$ receptors are the synaptic receptors for DA in the accumbens or, alternatively, that stimulation of $\delta$-receptor specifically potentiates $D_{1}$ responses. Finally, as shown by the similarity of the effects of intracerebroventricular and intra-accumbens (D$\mathrm{Ala}^{2}$ )deltorphin II and PLO 17, the accumbens is among the most influential sites for the motor effects of $\delta$ - and $\mu$-opioids in the forebrain, and this role can be clcarly distinguished from that of the caudate. 


\section{References}

Amalric M, Koob GF (1985) Low doses of methylnaloxonium in the nucleus accumbens antagonize hyperactivity induced by heroin in the rat. Pharmacol Biochem Behav 23:411-415.

Babbini M, Davis NM (1972) Time dose relationships for locomotor activity effects of morphine after acute or repeated treatment. Br J Pharmacol 46:213-224.

Blanchard SG, Lee PHK, Pugh WW, Hong JS, Chang K-J (1987) Characterization of the binding of a morphine $(\mathrm{mu})$ receptor-specific ligand: Tyr-Pro-NMePhe-D-Pro-NH ${ }_{2},{ }^{3} \mathrm{H}-\mathrm{PLO}$ 17. Mol Pharmacol 31: 326-333.

Broekkamp CLE, Phillips AG, Cools AT (1979) Stimulant effects of enkephalin microinjection into the dopaminergic A10 area. Nature 278:560-562.

Chang KB, Fong BTW, Pert A, Pert CB (1976) Opiate receptor affinities and behavioural effects of enkephalin: structure-activity relationship of ten synthetic peptide analogues. Life Sci 18:1473.

Chang K-J, Wei ET, Killian A, Chang J-K (1983) Potent morphiceptin analogs: structure activity relationships and morphine-like activities. J Pharmacol Exp Ther 227:403-408.

Costall B, Fortune DH, Naylor RJ (1978) The induction of catalepsy and hyperactivity by morphine administered directly into the nucleus accumbens of rats. Eur J Pharmacol 49:49-64.

Creese I, Iversen SD (1975) The pharmacological and anatomical substrates of amphetamine response in the rat. Brain Res 83:419436.

Daugé V, Rossignol P, Roques BP (1988) Comparison of the behavioural effects induced by administration in rat nucleus accumbens or nucleus caudatus of selective $\mu$ and $\delta$ opioid peptides or kelatorphan an inhibitor of enkephalin-degrading-enzymes. Psychopharmacology 96:343-352.

Di Chiara G (1990) In vivo brain dialysis of neurotransmitters. Trends Pharmacol Sci 11:116-121.

Di Chiara G, Imperato A (1988a) Drugs abused by humans preferentially increase synaptic dopamine concentrations in the mesolimbic system of freely moving rats. Proc Natl Acad Sci USA 85:5274-5278.

Di Chiara G, Imperato A (1988b) Opposite effects of $\mu$ and $\kappa$-opiate agonists on dopamine-release in the nucleus accumbens and in the dorsal caudate of freely moving rats. J Pharmacol Exp Ther 244: $1067-1078$

Di Chiara G, Morelli M, Porceddu ML, Gessa GL (1979) Role of thalamic gamma-aminobutyrate in motor functions: catalepsy and ipsiversive turning after intrathalamic muscimol. Neuroscience 4: 1453-1465.

Domino EF, Vasko MR, Wilson AE (1976) Mixed depressant and stimulant actions of morphine and their relationship to brain acetylcholine. Life Sci 18:361-376.

Erspamer V, Melchiorri P, Falconieri-Erspamer G, Negri L, Corsi R, Severini C, Barra D, Simmaco M, Kreil G (1989) Deltorphins: a family of naturally occurring peptides with high affinity and selectivity for delta opioid binding sites. Proc Natl Acad Sci USA 86:461-464.

Groppetti A, Ceresoli G, Mandelli V, Parenti M (1990) Role of opiates in striatal D-1 dopamine receptor supersensitivity induced by chronic L-dopa treatment. J Pharmacol Exp 253:950-956.

Havemann U, Kuschinsky K (1985) Locomotor activity of rats after injection of various opioids into the nucleus accumbens and the septum medial. Naunyn Schmiedebergs Arch Pharmacol 331:175-180.

Hillegart V, Ahlenius S (1987) Effects of raclopride on exploratory locomotor activity, treadmill locomotion, conditioned avoidance behaviour and catalepsy in rats: behavioural profile comparisons between raclopride, haloperidol and preclamol. Pharmacol Toxicol 60: 350-354.

Hyttel J (1983) SCH 23390-the first selective dopamine D-1 antagonist. Eur J Pharmacol 91:153-154.

Imperato A, Di Chiara G (1984) Trans-striatal dialysis coupled to reverse phase high performance liquid chromatography with electrochemical detection: a new method for the "in vivo" release of endogenous dopamine and metabolites. J Neurosci 4:966-977.

Imperato A, Di Chiara G (1985) Dopamine release and metabolism in awake rats after systemic neuroleptics as studied by trans-striatal dialysis. J Neurosci 5:297-306.

Imperato A, Di Chiara G (1986) Preferential stimulation of dopamine release in the nucleus accumbens of freely moving rats by ethanol. $J$ Pharmacol Exp Ther 239:219-228.
Kalivas PW, Wilderlow E, Stanley D, Breese G, Prange AJ (1983) Enkephalin action on the mesolimbic system: a dopamine-dependent and a dopamine-independent increase in locomotor activity. J Pharmacol Exp Ther 227:229-237.

Kelley AE, Stinus L, Iversen SD (1980) Interactions between D-Ala ${ }^{2}$ Met-enkephalin, A10 dopaminergic neurones and spontaneous behavior in the rat. Behav Brain Res 1:3-24.

Kelley AE, Lang CG, Gauthier AM (1988) Induction of oral stereotypy following amphetamine microinjection into a discrete subregion of the striatum. Psychopharmacology 95:556-559.

Konig JFR, Klippel RA (1963) The rat brain. Baltimore: Williams and Wilkins.

Latimer LG, Duffy P, Kalivas PW (1987) Mu opioid receptor involvement in enkephalin activation of dopamine neurons in the ventral tegmental area. J Pharamcol Exp Ther 241:328-337.

Longoni R, Spina L, Di Chiara G (1987a) Dopaminergic D-1 receptors: essential role in morphine-induced hypermotility. Psychopharmacology 93:401-402.

Longoni R, Spina L, Di Chiara G (1987b) Permissive role of D-1 receptor stimulation for the expression of D-2 mediated hehavioral responses: a quantitative phenomenological study in rats. Life Sci 41: 2135-2145.

Lubetzki C, Chesselet MF, Glowinski J (1982) Modulation of dopamine release in rat striatal slices by delta-opiate agonists. J Pharmacol Exp Ther 222:435-442.

Mansour A, Khachaturian H, Lewis ME, Akil H, Watson SJ (1988) Anatomy of CNS opioid receptors. Trends Neurosci 11:306-314.

Matthews RT, German DC (1984) Electrophysiological evidence for excitation of rat ventral tegmental area dopamine neurons by morphine. Neuroscience 11:617-625.

Mogenson GJ, Jones DJ, Yim CY (1980) From motivation to action: functional interface between the limbic system and the motor system. Prog Neurobiol 14:69-97.

Morelli M, Di Chiara G (1985) Catalepsy by SCH 23390 in rats. Eur J Pharmacol 117:179.

Morelli M, Fenu S, Di Chiara G (1989) Substantia nigra as a site of origin of dopamine-dependent motor syndromes induced by stimulation of $\mu$ and delta opioid receptors. Brain Res 487:120-130.

Ogren S-O, Hall H, Kohler C, Magnusson O, Sjostrand S-E (1986) The selective dopamine $\mathrm{D}_{2}$ receptor antagonist raclopride discriminates between dopamine-mediated motor functions. Psychopharmacology 90:287-294.

Pellegrino LJ, Pellegrino AS, Cushman AJ (1979) A stereotaxic atlas of the rat brain, $2 \mathrm{~d}$ ed. New York: Plenum.

Pert A, Sivit C (1977) Neuroanatomical focus for morphine and enkephalin-induced hypermotility. Nature 265:645-647.

Petit F, Hamon M, Fournie-Zaluski MC, Roques BP, Glowinski J (1986) Further evidence for a role of delta opiate-receptors in the presynaptic regulation of newly synthesized dopamine release. Eur J Pharmacol 126:1-9.

Pollock J, Kornetsky C (1989) Evidence for the role of dopamine $\mathrm{D}_{1}$ receptors in morphine induced stereotypic behavior. Neurosci Lett 102:291-296.

Portoghese PS, Sultana M, Takemori AE (1988) Naltrindole, a highly selective and potent non-peptide delta opioid receptor antagonist. Eur J Pharmacol 146:185-186.

Rothman RB, Westfall TC (1982) Allosteric coupling between morphine and enkephalin receptors in vitro. Mol Pharmacol 21:548-557.

Seeman P (1980) Brain dopamine receptors. Pharmacol Rev 32:229313.

Shippenberg TS, Bals-Kubik R, Herz A (1987) Motivational properties of opioids: evidence that an activation of delta receptors mediates reinforcement processes. Brain Res 436:234-239.

Stevens JR (1973) An anatomy of schizophrenia? Arch Gen Psychiatry 29:177-189.

Stinus L, Koob GF, Ling N, Bloom FE, LeMoal M (1980) Locomotor activation induced by infusion of endorphins into the ventral tegmental area: evidence for opiate-dopamine interactions. Proc Natl Acad Sci USA 77:2323-2327.

Tortella FC, Moreton JE, Khazan N (1978) Electroencephalographic and behavioral effects of $\mathrm{D}$ - $\mathrm{Ala}^{2}$-methionine-enkephalinamide and morphine in the rat. J Pharmacol Exp Ther 206:636-643.

Vaught JL, Takemori AE (1979) Differential effects of leucine and 
methionine enkephalin on morphine induced analgesia, acute tolerance and dependence. J Pharmacol Exp Ther 208:86-90.

Wise RA, Rompré PP (1989) Brain dopamine and reward. Annu Rev Psychol 40:191-225.
Yoshimura K, Huidobro-Toro JP, Way EL (1982) Potency of three opiate antagonists to reverse the inhibitory activity of dynorphin, enkephalins and opioid-like alkaloids on the guinea-pig ileum. Eur J Pharmacol 84:17-24. 